\title{
STRAH OD SMRTI U ROMANU ZIMSKO LJETOVANJE VLADANA DESNICE
}

\section{Melida Travančić}

UDK: 821.163.42-311.1Desnica, V.:364.27

Prethodno priopćenje

Sažetak: Autorica se bavi jednim od dosad slabije istraženih značenjskih slojeva romana Zimsko ljetovanje - strahom od smrti. Roman prati sudbinu grupe ljudi koji nakon bombardiranja Zadra bježe iz grada u obližnje selo Smiljevci. Desnica koristi povijesni okvir Drugoga svjetskog rata da bi prikazao sudbine malih, marginalnih ljudi, ali rat u ovom romanu nije tema po sebi, već je prikazan kao povijesni uzročnik koji proizvodi susret dvije grupe ljudi i njihovih kultura, koje se teško ili nikako ne prihvataju, a koje su prisiljene živjeti u zajednici. Strah od smrti zapravo je tematsko-motivska okosnica romana, dok rat ostaje tek mizanscenski prisutan. Roman donosi psihološku sliku stradanja pojedinaca, nad čijim se životima oslikava smrt kao posljedica povijesne tragedije čovječanstva. U Zimskom ljetovanju smrt je data kao sastavni dio života, ona je u svijesti i podsvijesti te pokreće i određuje stvari i događaje.

Ključne riječi: Vladan Desnica, Zimsko ljetovanje, strah, smrt, rat, psihološki lom, drugi

oman Zimsko ljetovanje (1950.) Vladana Desnice prati sudbinu grupe ljudi koji zbog ratnih dešavanja ostaju bez zavičaja, pripadnosti i perspektive. ${ }^{1}$ Radnja obuhvata period od 1943. do 1944., odnosno počinje bombardiranjem Zadra od strane savezničkih snaga. Iako je radnja smještena u povijesni kontekst Drugoga svjetskog rata, ovaj roman nije primjer klasične ratne, odnosno poslijeratne književnosti. Izuzmu li se drugo - unutar

1 O ovom je romanu već bilo riječi na dosadašnjim Desničinim susretima, ali su se autori bavili drugim aspektima. V. Davor Dukić, „Nekoliko imagoloških opaski o Zimskom ljetovanju i Desničinim susretima“, Desničini susreti 2005. - 2008. Zbornik radova (ur. Drago Roksandić i Ivana Cvijović Javorina), Zagreb 2010., 149-156; Zoran Kravar, „Zimsko ljetovanje Vladana Desnice pod ideološkokritičkim lećama“, Desničini susreti 2010. Zbornik radova (ur. Drago Roksandić i Ivana Cvijović Javorina), Zagreb 2011., 9-17; Tihomir Brajović, „Ironija i kolektivna memorija: Desnica, Krleža, Andrić“, Isto, 31-38; Luca VAGLio, „Vidovi policentrizma i problematičnosti u romanu Zimsko ljetovanje Vladana Desnice“, Isto, 101-108; Miljenko BulJAC, „Poetika Zimskog ljetovanja - prvi tipološki krug literarnosti Vladana Desnice“, Vladan Desnica i Split 1920. - 1945. Zbornik radova sa znanstvenog skupa Desničini susreti 2014. (ur. Drago Roksandić i Ivana Cvijović Javorina), Zagreb 2015., 343-358; Vladimir Rismondo, „Roman Zimsko ljetovanje Vladana Desnice u svjetlu kulturalnih studija“, Split $i$ Vladan Desnica 1918. - 1945.: umjetničko stvaralaštvo izmedu kulture i politike. Zbornik radova sa znanstvenog skupa Desničini susreti 2015. (ur. Drago Roksandić i Ivana Cvijović Javorina), Zagreb 2016., 131-143; Marina Protrka Štimec, „'Kineskim zidom odvojeni’. Politike identiteta, nejednakosti i isključivanja u Desničinu Zimskom ljetovanju“, Hrvatsko-srpski / srpsko-hrvatski interkulturalizam danas. Zbornik radova s medunarodnoga znanstvenog skupa Desničini susreti 2016. (ur. Drago Roksandić), 
kojeg se najavljuje ratna katastrofa - i treće poglavlje - u kojem se direktno govori o avionskim napadima i njihovim posljedicama - tokom cijelog romana rat nije u prvom planu. On jeste svojevrsni pokretač radnje, jer od njega, to jest od njegovih posljedica, grupa Zadrana bježi u obližnje selo. Međutim, čim pronađu utočište, rat se potiskuje u drugu stranu. Tako da je i u govoru likova rat „prisutan onoliko koliko je odgovoran za njihov trenutni inkomoditet, ali je odsutan kao političkopovijesni događaj“.2 „Buka istorije“ (Kiš) ovdje se javlja u pozadini radnje; iako autor nastoji da se ogradi od tog historijskog loma, on je ipak mizanscenski kontinuirano prisutan. Unutar Zimskog ljetovanja umnogome se potvrđuje upravo ono što Hamvaš izdvaja kao karakteristiku romana s historijskim diskursom u pozadini: „Pored takozvane realne istorije roman postavlja čovekovu ličnu povest. Katkada i nasuprot njoj. Ali u svakom slučaju s odvojenim početkom, onu prethodnu katkada presecajući, nekada ostajući izvan nje, nekad prodirući u nju (...).“3

U romanu se prikazuju realistični događaji, indirektno se govori o traumama prouzrokovanim ratom, bilježi se potpuni lom (i fizički i duhovni), a sve to na primjeru jedne manje skupine ljudi, izbjeglica. Iz razorenoga grada, pod teretom historijskog loma, u nastojanju da prežive ratne strahote, grupa Zadrana utočište traži u selu Smiljevci nadomak grada, koje je, činilo se, udaljeno od ratnih katastrofa. Desnica koristi povijesni okvir da bi prikazao sudbine malih, marginalizovanih ljudi, ali rat u ovom romanu nije tema po sebi; on je prikazan kao povijesni uzročnik koji proizvodi susret dvije grupe ljudi koji su „podijeljeni civilizacijskom demarkacijom “ ${ }^{\text {“4 }}$ - oni se teško ili nikako ne prihvataju, a prisiljeni su na suživot. Dolaskom i smještanjem u Smiljevce, Zadrani su uvjereni da pronalaze spas od rata i smrti, ali silom prilika nalaze se u novoj, donekle nepoznatoj i umnogome različitoj sredini - za njih je selo „terra incognita, mjesto bez značenja, od kojeg kao da su 'odijeljeni kineskim zidom ili pojasom pustoši', hiljadama, a ne petnaest kilometara“.5 Iako nisu bili udaljeni hiljadama kilometara, ovo je njihov prvi stvarni susret sa selom. Stoga je dolazak na selo za njih „imao donekle čar puta u dalek i egzotičan kraj“, dok su ih seljani „gledali u šutnji, raskolačenih očiju, kao ljude koji dolaze sa drugog svijeta“. ${ }^{6}$ Izbjeglice i mještani u neprestanom su ambivalentnom odnosu privlačenja i odbijanja, primorani ponekad zajedno djelovati (kao što je to slučaj smrti stare popadije), ali su, veoma često, u različitim oblicima sukoba te, na koncu, bez mogućnosti pronalaska vrijednosti koje bi njihove razlike poništile ili barem neutralizirale. ${ }^{7}$ Zadrani prema Smiljevcima i njegovim stanovnicima za-

Zagreb 2017., 199-212. U ovom radu fokus je na strahu od smrti kao pokretaču radnje. O romanu Zimsko ljetovanje napisane su mnogobrojne studije i gotovo da nema ni jednog značenjskog sloja romana koji detaljno nije opserviran, osim možda straha od smrti, koji su mnogi književni teoretičari i kritičari uočili, ali mu nije posvećena dovoljna pažnja. Ponešto je kazano tek u naznakama, no cjelovitog teksta nema. Smrt je prisutna od prvog do posljednjeg poglavlja romana, ona je u svijesti i podsvijesti likova te je zanimljiv način na koji se likovi sa njom nastoje (ne) suočiti.

Bela Hamvaš, Teorija romana, Beograd 1996., 19.

4 Z. Kravar, „Zimsko ljetovanje Vladana Desnice pod ideološkokritičkim lećama“, 12.

5 M. Protrka Štimec, "Kineskim zidom odvojeni'“, 202.

6 Vladan Desnica, Zimsko ljetovanje, Zagreb 1968., 41.

7 Od samog je početka romana egzistencijalna pozicija izbjeglica (razaranje doma, bijeg te dolazak u Smiljevce) beznadežnost i nepripadnost. Oni s vremena na vrijeme odlaze u Zadar (nadziru imovinu, donose preostale vrijednosti, traže dozvolu od vlasti da napuste Zadar i život nastave u Italiji), ali mu više ne pripadaju, ne sudjeluju aktivno u 
uzimaju superioran stav te je jasno postavljena razlika između kulture grada i sela, odnosno „napredne i nazadne kulture“. ${ }^{8}$

Roman obiluje primjerima koji ocrtavaju Desničinu ironiju i distancu od malograđanskih svjetonazora. To je zapravo suština njegove narativne strategije, a ogleda se prije svega kroz reprezentaciju razlika, odnosno predodžbe koje građani „srednje ruke“ imaju o selu i njegovim stanovnicima. Prostor sukoba kultura predočen je odmah na početku te je on jedan od osnovnih slojeva romana koji je realiziran „nizom postupaka u kojima postaje vidljivo da se prividna distanciranost i verizam pripovjedača udružuju s ironijskim iskazima“, a distancirani pripovjedač prikazuje se kao „svjesno hinjeni“ te su opisi likova „na strateškim mjestima obojeni suptilnom ironijom, bezglasnim čuđenjem ili tek znakovitom šutnjom“.? Veliki dio radnje romana postavljen je na odnosu grad - selo, odnosno predodžbama koje imaju jedni o drugima i na tim relacijama može se pratiti asocijativno-aluzivna priča o nesporazumu, nerazumijevanju, time i neprihvatanju drugih, drugačijih kao trajnom stanju čovjekove egzistencije.

Radnja romana prati život u Smiljevcima, sa akcentom na izbjeglicama, čija se sudbina, na kraju, manifestira kao tragična priča o ljudima koji nisu imali nikakav izbor: njihov grad i dom razorio je rat, zatim istom jačinom i njihovu porodicu, a na koncu i njih same. Brojni su primjeri unutar romana o tome kako se rat manifestira i preseljava u/na čovjeka te na koji način uzrokuje potpuni moralni i psihološki lom individue. U potpunosti je ocrtana unutrašnja borba likova da prevladaju nedaće koje su ih zadesile. Najprije se moraju suočiti sa zlom i uništenjem (s početka romana nesvjesni su ozbiljnosti situacije te su prikazani kako hladnokrvno posmatraju bombardiranje), neposredno potom suočavaju se sa smrću (kroz prizore mrtvih na ulici), a zatim bijegom iz grada nastoje spasiti vlastiti život. Međutim, i u Smiljevcima, za koje misle da su sasvim sigurni, nailaze na razne nedaće. Ni ovo mjesto nisu mimoišle ratne katastrofe, koje se nešto drugačije manifestiraju, npr. kroz ubistva suseljana pod okriljem noći, o kojima Smiljevčani kolektivno šute jer se i sami plaše smrti. S jedne strane, roman prikazuje ljudsku težnju da se od smrti umakne, dok je, $s$

njegovom životu. S druge strane, nastanjujući se u Smiljevcima, prestali su biti dio svoga dosadašnjeg svijeta, a nisu u mogućnosti da se integriraju u život sela. Smiljevci zauzimaju takav geografski položaj da Zadrani jasno vide rušenje svoga dosadašnjeg života, čuju eksplozije, posmatraju velike tamne oblake koji se izdižu iznad grada. Razaranje Zadra i smrt sugrađana kod njih ne izaziva nikakve emocije; oni kao da su vremenski daleko od rata, kao da su Smiljevci izmješteni iz realnosti i postoje u „paralelnoj stvarnosti koja samo registrira događaje iz urbanog realiteta“. Posrijedi je zapravo šok, zatim bespomoćnost i apsolutna nemogućnost da se na bilo šta utiče. $S$ druge strane, Smiljevčani nisu neutralni posmatrači, nego „likuju nad sudbinom grada i njegovih stanovnika“ jer Zadrane doživljavaju ,iz perspektive vlastitog normativnog ' jastva'“. Pozicija Smiljevaca, kao i njegovih stanovnika, spram grada, je marginalna. Usp. V. Rismondo, „Roman Zimsko ljetovanje Vladana Desnice u svjetlu kulturalnih studija“, 134.

8 Mirna Sindičić Sabljo, „Predodžbe o ruralnoj sredini u Zimskom ljetovanju Vladana Desnice“, Fluminensia, 23/2011., br. 1, 140. Kroz interdisciplinarnu oblast imagologije autorica se bavi isključivo posmatranjem predodžbi koje u ovom romanu Zadrani imaju spram sela i njegovih stanovnika te se rad i temelji na istraživanju konstrukcije i reprezentacije njihovog/ih identiteta. Predmet istraživanja jesu iskrivljene heteropredodžbe koje Zadrani imaju spram sela i njegovih stanovnika, a takve predodžbe nastale su isključivo zbog nedovoljnog poznavanja drugog. Autorica polazi od činjenice da su urbana i ruralna kultura u potpunosti različite, ali je prvenstveno zanimaju predodžbe i predrasude koje jedna kultura ima o drugoj te način na koji su ove dvije kulture povezane, odnosno kako se slika koju Zadrani grade o selu reflektira (tzv. faza ogledala) na njih same. Rad nema za cilj istinski prikazati pripadnike jedne grupe (Smiljevčane), niti odgovoriti na pitanje ko su i kakvi su oni, već prikazati kako su drugi oblikovani pomoću književnog diskursa.

9 M. Protrka Štimec, „'Kineskim zidom odvojeni'“, 201-202. 
druge strane, prikaz „izgubljene“ grupe ljudi, koja se očajnički trudi prilagoditi životu u vremenu velikih historijskih promjena koje presudno određuju ljudske sudbine, pretvarajući ih nerijetko u tragične.

Tema smrti „opsjeda“ čovječanstvo od njegovog postanka pa nije iznenađujuće što je predmetom brojnih opserviranja u različitim oblastima, a zavisno od fokusa istraživanja pripisuju joj se različita značenja - od sociološkog, psihološkog, medicinskog, teološkog, filozofskog. Također, smrt je veoma česta i značajna tema u umjetnosti (slikarstvo, muzika, film, književnost). Ovdje je, prije svega, važno kazati da se smrt, odnosno strah od nje, u savremenoj kulturi gotovo potpuno negira i prema tom strahu odnosimo se kao da on uopće ne postoji. Freud tvrdi da je naš strah od smrti veoma čudan, jer čovjek se ponaša tako što nastoji smrt „eliminirati iz života“ ili još eksplicitnije konstatira da mi, zapravo, želimo smrt „mrtvo prešutjeti; mislimo na nju - kao na smrt“ ${ }^{10}$ Iz našeg života i ponašanja ne može se zaključiti da smo mi svjesni smrti te da je prepoznajemo kao nešto što je neizbježno i što će sasvim sigurno doći prirodnim slijedom. ${ }^{11}$ Veoma često se zanemaruje činjenica da svi umiremo i da se sasvim sigurno na neki način i u nekom periodu života suočavamo sa strahom od smrti.

Kada govorimo o razumijevanju fenomena smrti i strahu od nje u današnjem društvu, ističu se različita filozofska razmišljanja, koja se mogu podijeliti na dva oprečna gledišta. $S$ jedne strane, filozofi ustrajno nastoje da pronađu zadovoljavajuće osmišljavanje smrti i da životu daju smisao. S druge strane, nemoguće je u današnjem kontekstu govoriti o smrti a da se ne istakne Epikurovo promišljanje koje umnogome karakterizira današnjeg čovjeka. Epikur naglašava da nas se smrt ništa ne tiče, jer provesti život u stalnom promišljanju i strahu od smrti nema nikakvog smisla ni vrijednosti, čovjek se tako lišava sreće jer „dok ima nas nema smrti, kada nastupi smrt tada više nema nas". ${ }^{12}$ Smrt se tako ne tiče ni živih ni mrtvih jer žive ne dodiruje, a mrtvi ne postoje više. Prema Epikuru, glavni uzrok ljudske patnje jeste strah od smrti koji ne dopušta uživanje u životu. Zapravo, epikurejska misao temelji se na tome da se nemamo čega plašiti u slučaju smrti, jer mi smo mrtvi i ništa više ne osjećamo, a zanemaruje se činjenica da se strah od smrti ne sastoji u strahu od stanja koje dolazi nakon nje (barem ne isključivo od tog stanja), već u strahu od blizine smrti. Nema sumnje da je ova Epikurova tvrdnja odličan način potiskivanja osjećaja stra-

10 Sigmund Frojd, Mi i smrt. Našs stav prema smrti: dosad neobjavljeni rukopisi i predavanja (prir. Žarko Martinović i Milica Martinović), Beograd 2001., 39.

11 Sigmun Freud u navedenom predavanju govori o načinu na koji čovjek pretpovijesti i današnji čovjek razumijevaju smrt. Čovjek pretpovijesti se prema smrti odnosi proturječno. $S$ jedne strane, smrt je predstavljala uništenje života, čemu je težio kada je bila riječ o drugom. S druge strane, poricao je smrt, smatrajući je ništavnom. Postavlja se pitanje kako je ovako drastično promišljanje o smrti moglo biti sadržano u jednoj individui. Freud tvrdi da jeste, jer se čovjek odnosi drugačije prema smrti drugog, stranog, neprijatelja, smatrajući je uništenjem života koje on nastoji uzrokovati (rat, ubistvo neprijatelja). Radikalno drugačije stajalište zauzimao je prema vlastitoj smrti ili smrti bližnjih, tako što je smrt poricao i smatrao je ništavnom. Odnos prema smrti od pretpovijesnog čovjeka do danas nije se mnogo promijenio. Smrt kao okončanje (vlastitog) života uvijek je za čovjeka bila nezamisliva i nezbiljska, jer „naše nesvesno zauzima prema smrti isto ono stajalište koje zauzima čovjek pretpovesti“" a takvo stajalište prema smrti jeste da naše nesvjesno uopće ne vjeruje u vlastitu smrt i ne može je pojmiti, tako da je i danas skoro neprihvatljivo govoriti o smrti.

12 Epıkur, „Pismo Menoikeju“, u: Branko BošNJAK, Filozofija od Aristotela do renesanse i odabrani tekstovi filozofa, Zagreb 1983., 145. 
ha od smrti, ali samo do onog trenutka kada se suočimo sa smrću. Svojom blizinom smrt nameće razmišljanje u kojima se strah redovno javlja. Prihvatiti smrt (bez straha) u takvim je situacijama rijetkost. ${ }^{13}$

$\mathrm{Na}$ samom početku romana Zimsko ljetovanje, u trećem poglavlju, smrt je prikazana kroz uništenje grada i iskasapljena tijela koja leže na ulici. Još je potresnija slika ubijenih mališana čija tijela eksplozija podiže u zrak „pa su padajući s visine zapeli na telegrafske žice pored puta; vise tako dječja tjelešca, presumićena preko žice kao djetinje haljinice izvješene na sušenje“. ${ }^{14}$ Pred takvim prizorima smrt preživjelima postaje konkretna i bliska te je nastoje prihvatiti na što jednostavniji i praktičniji način. Likovi se kreću u „prostoru smrti“ (Blanchot), a njenu blizinu osvijestili su i opredmetili onog trenutka kada se suočavaju sa mrtvima na ulici. Nakon bombardiranja i ugledanih prizora mrtvih na ulici preživjelima se otvarala ,jedna nova dimenzija“ $\mathrm{i}$ uporedo $s$ njom ,jedan novi oblik straha" ${ }^{\text {"15 }}$, strah pokrenut recentnim događajem: ratom i smrću. Ovakvo, slobodno možemo kazati, iznenadno suočavanje sa mrtvima, preciznije sa smrću - jer ništa nije dalo nagovijestiti kobne posljedice po građane Zadra - budi u preživjelima spoznaju o jedinoj izvjesnoj čovjekovoj istini: smrti.

Likovi s početka romana uopće ne razmišljaju o smrti, ${ }^{16}$ čak i kada padaju prve bombe, oni ne bježe, jer misle da je sve to „kratkog daha“ i da se njima ništa ne može dogoditi. U potpunosti izostaje svijest o blizini smrti, a time nema ni straha od nje. Međutim, kako smrt postaje sve bliža, želja za preživljavanjem je sve snažnije izražena, a strah od smrti zauzima mjesto glavnog pokretača života. Ovdje je, zapravo, riječ o ljudima koji se nalaze u neposrednoj blizini smrti te su je za jedan trenutak izbjegli, odnosno odgodili. To su učinili bijegom od mrtvih, ali i živih kojima treba pomoć, bijegom od bombi, razaranja, rata, bijegom od/iz doma. Likovi u ovom poglavlju romana u potpunosti su koncentrirani na sebe, na vlastiti opstanak, pri čemu zaboravljaju i na vlastitu porodicu. Ako se u takvim momentima mogu zaboraviti najbliži, onda nije iznenađujuće da u suočavanju sa mrtvima na ulici nema drame svijesti i savjesti. Pored mrtvih tijela prolazi se užurbano, šuteći, pa i ravnodušno, ni jednog trenutka nema emotivne reakcije. U preživjelima preovladava, dakle, „ludi strah i nagon da bježe, s prastarom panikom s kojom su ljudi bježali od gubavaca“. ${ }^{17}$

13 Postoje dva različita mišljenja o tome kako se u čovjeku oblikuje strah od smrti. Prema jednima, on je prirodni fenomen. To je strah koji je u čovjeku prisutan od njegovog rođenja, jer čim se rodimo, počinjemo nositi sa sobom strah od smrti. Nju niko ne može izbjeći; možda samo u nekim periodima našeg života nismo svjesni neizbježnosti smrti, ali strah je prožimajući faktor koji dominira našim životima. Prema drugima, strah od smrti nije urođen, već se javlja tokom čovjekovog razvoja i usko je vezan sa nagonom smrti o kojem je Freud govorio.

14 V. Desnica, Zimsko ljetovanje, 51.

15 Isto, 49.

16 U ovom kontekstu važno je napomenuti da postoje dva suprotna mišljenja o tome kako savladati, odnosno kako se suočiti sa strahom od smrti. Prema jednima, čovjek ne može djelovati ako će stalno misliti na smrt. Jednostavno rečeno, ne bi bilo moguće funkcionisati ako će nam smrt stalno biti „pred očima“ i ako ćemo neprestano biti opterećeni činjenicom da ćemo jednog dana umrijeti. Da bi pojedinac mogao normalno funkcionisati u savremenom svijetu, on ne može i ne smije misliti na smrt. $S$ druge strane, javlja se i mišljenje da čovjek neprestano mora misliti na smrt jer će jedino tako smanjiti svoj strah od nje. Tako npr. Michel de Montaigne u knjizi Ogledi, u poglavlju „Da filozofirati znači navikavati se na smrt", ističe da je meta našeg životnog puta smrt. Ako se nje plašimo, ne možemo da napravimo ni korak naprijed. Neprestano misliti na smrt, znači s njom se suočiti i prevladati strah od umiranja. Čovjek koji u tome uspije, naglašava Michel de Montaigne, jeste slobodan čovjek. V. Mišel de Montenj, Ogledi, Beograd 1967., 30-31. 
Ovaj dio romana reprezentativan je pokazatelj malograđanskog morala u jednoj vanrednoj situaciji, u kojoj je do detalja prikazana zaostalost i egoizam. Spomenimo samo susret s čovjekom u potpunosti izgubljenim i prekrivenim prašinom, pred kojim oni bježe kao pred „spodobom“, strahujući da ih ne dodirne. Preživjeli mrtve ignoriraju jer tako nastoje potisnuti užas koji vide, ne bi li na taj način eliminirali smrt iz svoje neposredne blizine. ${ }^{18}$

U ovom dijelu romana centralno mjesto zauzima Ernesto Doner, čovjek koji se kreće kroz bombardovani grad, bježi od mrtvih uvjeren da tako spašava vlastiti život. ${ }^{19} \mathrm{I}$ on, ali i ostala grupa likova koji se javljaju s početka te preživljavaju zračni napad, pognute glave prolaze pored mrtvih. Nereagiranjem, šutnjom i potiskivanjem prizora mrtvih likovi se brane od činjenice da je smrt sasvim blizu, dok je, s druge strane, njihov bijeg od mrtvih, odnosno smrti, zapravo nesvjesni odbranbeni mehanizam i želja da sve što u tom času vide, užas koji ih okružuje, izbjegnu i prežive. Ovdje je posrijedi racionalni strah za vlastiti život, koji je sasvim realan i u datoj situaciji opravdan jer u čovjeku preovladava nagon da izbjegne ili da barem pokuša izbjeći opasnost. Uvjereni da mrtvima ne mogu pomoći, preživjeli se fokusiraju na sebe i kreću u neizvjesnu borbu za opstanak.

Također, potrebno je naglasiti da je u ovom poglavlju romana riječ o smrti drugog, nekoga ko likovima nije blizak, mrtve čak i ne poznaju ili ih - zaokupljeni sobom - ne mogu prepoznati te zbog njih ne tuguju. Nameće se pitanje šta smrt drugog znači za preživjele, šta ona u njima izaziva? Smrt je uvijek na neki način potresna i podsjeća da ćemo i mi umrijeti, posebno kada je riječ o nasilnoj smrti, a u ovom slučaju riječ je o smrti uzrokovanoj ratom, to jest avionskim bombama. Tako da smrt drugih opominje da se i njihov život ili život njima bliskih ljudi može prekinuti na isti način i svakog časa. $S$ jedne strane, pogled na mrtve stvara strah koji paralizira - pred prizorom otkinutih udova, popolovljenih tijela, otkinute glave, živih zatrpanih ljudi u podrumu bez mogućnosti izbavljenja. S druge je, pak, strane smrt drugog jedini mogući pristup sopstvenoj smrti jer se u trenutku kada gledamo mrtvog drugog mi suočavamo sa svojim najvećim strahom - strahom od smrti, umiranja, raspadanja. Pored svih navedenih značenja, smrt drugog u ovom slučaju ima i značenje javnog događaja koji pokreće zajednicu da reagira, što oni čine bijegom. Tako iz pasivnog stanja - kada na početku romana lijeno posmatraju avione, nesvjesni opasnosti -

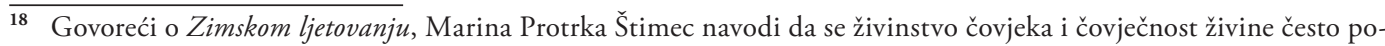
javljuje kao motiv ovog romana. Autorica, pored nekoliko scena koje svjedoče o tome, izdvaja i onu bombardiranja Zadra, naglašavajući da „zaborav drugih, čak i najbližih, okretanje glave od stradalih pod ruševinama dovodi do zaključka o tome kakva je čovjek živina.“ V. M. Protrka Štimec, „Kineskim zidom odvojeni”“, 206. Osim što se ovom slikom prikazuje kolika je čovjek, zapravo, živina, s druge strane, prikazuje se izgubljenost i nemoć čovjeka pred prizorima ratnog užasa, koje za sobom ostavlja avion. Posrijedi je situacija u kojoj se likovi prvi put nalaze šokirani prizorima koje vide, potpuno su izgubljeni, što svakako nije opravdanje za bijeg od povrijeđenih. Iz takve situacije u likovima se isključivo javlja „slijepi nagon samospasavanja“, kako to imenuje Desnica, nemar i nebriga za ostale članove kolektiva, pa i za najbliže.

19 U nastojanju da spasi vlastiti život, Ernesto Doner je u tolikoj mjeri koncentriran na sebe da zaboravlja na porodicu. U tome nije usamljen jer su i ostali ljudi iz grupe prikazane na početku romana, koji bježe pred bombama, zaokupljeni isključivo sobom. Dio u kojem Doner „iznenada“ pomisli na porodicu, zapravo je onaj koji na najreprezentativniji način svjedoči o čovjekovoj koncentriranosti isključivo na sebe i spas vlastitog života: „Nego, tamo negdje, kako je izgledalo baš u pravcu njegove kuće, dizao se velik stup dima. 'Gle boga mu! Dosad nisam ni pomislio na moje! Kao da sam sâm na svijetu!’... Osjeti da je u taj isti čas i u drugima proklijala ista misao. Jer su se svi naglo pokunjili i ponovo ušutjeli. 'Sto mi je od žene, od djeteta?' upita se. Ali ih ni sad ne spomenu. Tek pogleda ispod oka na ostale da provjeri. - Ma l'uomo è proprio una bestia! - izvali Minuči, naoko bez veze. 'A-ha! I kod ostalih je isto!' odlakne Ernestu."V. Desnica, Zimsko ljetovanje, 52. 
prelaze u aktivno stanje, koje se manifestira kroz užurbano sakupljanje neophodnih stvari i bijegom u sela nadomak Zadra.

Ernst Tugendhat u knjizi $O$ smrti postavlja elementarno pitanje: Šta je tačno to od čega strahujemo kada je riječ o strahu od smrti? Tugendhat ne nudi konkretan odgovor, jer takav odgovor i ne postoji, nego objašnjava da je strah od smrti proces koji neizbježno ima subjektivnu polaznu tačku, a na njega utiče pretpostavka o blizini/daljini smrti. ${ }^{20}$ Ovdje likovi vjeruju da će, ako ostanu u gradu, uskoro umrijeti. To je strah od jasno definiranog događaja, u ovom slučaju rata, odnosno bombardiranja kao vanjske prijetnje životu. Tugendhat to imenuje „vegetativnim strahom od smrti“ ${ }^{21}$ On se ispoljava kada neko počne vjerovati da je u opasnosti i da će uskoro umrijeti. Uzrokuje ga niz vanjskih faktora. Takva vrsta straha javlja se, na primjer, u slučaju kada je neko progonjen - jedna prijeteća situacija koja često može da ima (ali i ne mora) smrtni izhod. Ljudi iz grada bježe pred smrću jer su progonjeni užasom rata, a bombe su jasna i dovoljna vanjska prijetnja koja ih pokreće. Tako se i radnja romana premješta iz Zadra u Smiljevce, mjesto u kojem izbjeglice pokušavaju normalno živjeti.

Međutim, ni u Smiljevcima neće naći svoj mir. Prvo se suočavaju sa smrću stare popadije, čiji život, doduše, nije nasilno okončan. I Zadrani i Smiljevčani njenu smrt prihvataju kao nešto neminovno i prirodno. Ta smrt ni na koji način ne utiče na kontinuitet njihovog života. Ravnodušnost nad nesrećom, odnosno smrću drugog, ovdje nije ništa drugačija nego što su to likovi pokazali bježeći od iskasapljenih tijela. I ovdje oni, uslovno kazano, bježe od mrtvaca. Popadija tako ostaje nesahranjena nekoliko dana jer su ljudi zaokupljeni sobom, ne žele remetiti vlastite planove i niko ne može dati kola i konje da se njen leš odveze na groblje i tamo pokopa. U ovoj sceni, prema navodima Radomira Konstantinovića, javlja se osjećanje „opšte samoće i napuštenosti, saznanje da svaki živi samo za sebe“ te ono „raste do monstruoznih razmera". 22 To će potvrditi i Ićan na sprovodu - bacajući grumen zemlje u raku, on će uzviknuti: „Eto joj. Dosta se i naživila!“23

Ni nakon ove smrti nema tugovanja, žalosti ni suza jer bilo bi „deplasirano da su [se], za tako starom i skoro sasvim tuđom osobom, brisale suze ili držale rupčić pod nosom“ “ ${ }^{24}$ Smrt stare popadije još je samo jedan pokazatelj koliko je „prisilna“ zajednica Smiljevčana i Zadrana disfunkcionalna. Naime, riječ je o tome da grupa koja dopušta da neko od njenih članova umre, a da ne bude žalovanja za njim, tj. da ne bude oplakan, samim tim svjedoči koliko toj zajednici nedostaje moralno jedinstvo i kohezija. Nakon ove smrti život se nastavlja uobičajenim tokom, vode se isprazni razgovori da bi se ispunila svakodnevnica. $\mathrm{Ni}$ jednog trenutka u romanu smrt ne budi razmišljanja o onostranom i metafizičkom, već

20 Ernst Tugendhat, $O$ smrti, Loznica 2010., 14. Tugendhat smatra da filozofija može doprinijeti razumijevanju smrti. Polazi od poznatih mišljenja o smrti, za koja smatra da ih, prije svega, treba objasniti, a zatim dopuniti njihove „praznine“. Ističe da ga ne zanimaju mišljenja postavljena na vjeri u život poslije smrti - na ljudsko biće gleda isključivo kao na segment biološkog razvoja. Njega, prije svega, zanima jasna svijest o konačnosti života i blizini/daljini smrti. U fokus svoga istraživanja postavlja pitanje zašto ljudi (čak i veoma stari) žele da odlože trenutak smrti? Naglašava da je nejasno čega se to plašimo kada se plašimo smrti, ako se smrti uopće i plašimo.

21 Isto, 12.

22 Radomir Konstantinović, „Vladan Desnica ili konačna forma“, u: V. Desnica, Zimsko ljetovanje, 183.

23 V. Desnica, Zimsko ljetovanje, 169-170.

24 Isto, 113. 
isključivo o ovozemaljskom i materijalnom. I sami će likovi nekoliko puta ponoviti da je smrt nemoguće izbjeći i da je ona jedino iskustvo koje dijele svi ljudi u svijetu. Tako poslije sprovoda popadije šjor Karlo kaže Ernestu na talijanskom: „Cosi finiremo tutti!“25 Sličnu rečenicu izgovorit će i Zadranin Baldasar Dètriko. Na vijest da je po svoj prilici umro šjor Karlo konstatirat će: „He, šta se može! Tako ćemo, prije ili poslije, svi!“" ${ }^{26} \mathrm{Ni}$ bolest šjora Karla izbjeglice mnogo ne dotiče, vrlo brzo ga prebole i ne znajući sa sigurnošću da li je mrtav ili živ, oni razmišljaju kako da ga pokopaju, da se iznova ne bi suočili sa problemima kakve su imali prilikom sahrane popadije. Bez obzira na smrt koja ih neprestano okružuje, niko od likova ne vjeruje da će baš on uskoro umrijeti jer, riječima Ernesta Donera, „kad smrt najzad dođe, došla je iznenada“. ${ }^{27}$ Potom nastavlja: „To vječito iznenađujuće kod smrti, to je, valjda, njeno, njeno svojstveno, jedan vid njene suštine - naprosto ona sama!" ${ }^{28}$ Prema psihoanalitičkoj školi, ovo je sasvim prirodna čovjekova reakcija jer „duboko u sebi - niko od nas - ne veruje u sopstvenu smrt. Nju uopšte ne možemo da zamislimo. U svim pokušajima da odslikamo ono što će biti posle naše smrti, ko će nas žaliti (...) primećujemo da smo uistinu još uvek tamo, kao posmatrači. “29

Mnogo su strašnije i potresnije vijesti o ubistvima suseljana pod okriljem noći. Ukazujući na neideologičnost Desničinog romana, Zoran Kravar ova ubistva karakterizira kao „krvave obračune među seljacima“, naglašavajući da Desnica njihove protagoniste ne povezuje ni sa jednom ideologijom, odnosno zaraćenom stranom, nego sa „privatnim svađama, sa zapamćenim uvredama i nepravdama i, ponajviše, s moći kojom posjedovanje vatrenog oružija djeluje na dušu seoskog primitivca“. ${ }^{30}$ Strah i uznemirenje za Zadrane, veće i od samih ubistava, predstavljala je nemogućnost govora o tome jer u takvim razgovorima Smiljevčani nisu željeli učestvovati, niti izričito spomenuti počinitelje tih (ne)djela. Razlog za kolektivnu šutnju Smiljevčana o temi ubistava lako je pronaći: strah za vlastiti život. Niko ne zna, možda bolje reći, ne želi da zna, zbog čega se ubistva događaju, ko ih naređuje, niti ko ih izvršava; niko od Smiljevčana ubistva ne osuđuje, čak njihove počinitelje ne naziva pogrdnim imenima, nego se sve prešutno pripisuje momcima od šesnaest, sedamnaest godina koji su uzeli oružje. Pored toga što osjećaju strah za vlastiti život, Smiljevčani šutnjom zapravo ignoriraju te događaje, te u njima ne žele učestvovati ni na koji način, dakle, ni kroz razgovor. Osim straha od smrti, ovdje je prisutan i strah od skrivenog i opasnog drugog.

Smiljevčani od ubistava okreću glavu, jer u njima vide direktnu opasnost za vlastiti život. Na taj način smrt se nastoji potisnuti, ignorirati, a s moralne strane ne čini se ništa da se zločini spriječe. Tako i oni postaju poput Zadrana s početka romana, koji pored mrtvih, ali i povrijeđenih, prolaze šuteći te za spas vlastitog života žrtvuju moralno i etičko u sebi. Za razliku od Smiljevčana, Zadrani će nastojati pronaći odgovor, više iz radoznalosti nego zbog istinskog žaljenja stradalih, pa će tako šjor Karlo nekoliko puta upitati Ićana o ubi-

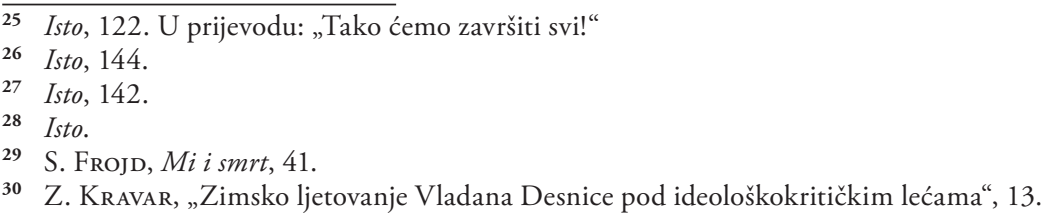


stvima i insistirati na odgovoru. Ićan će, pomalo nervozno, ubistva pripisati ratu, vremenu kada svako može ubiti svakoga, bez bilo kakvih posljedica: „Poškvario se svijet, eto ti! Ovaj rat, ovaj đava, mladost nezaglavljena, svak ima pušku - eto ti šta je."31 Tako rat, odnosno njegove posljedice svoj odjek nalaze i u Smiljevcima, ulivajući strah u njegove stanovnike. Iako su kroz cijeli roman prikazani u nekoj vrsti sukoba, bez mogućnosti preovladavanja razlika, suživota ili uvažavanja onog drugog, Smiljevčani i Zadrani imaju nešto zajedničko: strah od smrti i želju da se preživi rat. $S$ tom razlikom da je intenzitet straha od/pred smrću umnogome drugačiji kod likova ovog romana i nije isti u gradu i selu, za koje se činilo da je udaljeno od ratnih katastrofa. Strah od smrti kod Zadrana s početka romana izuzetno je jasan i konkretan: bombardiranju su izloženi svi stanovnici Zadra. U Smiljevcima je situacija znatno drugačija, nije jasno izražen objekat straha, ubistva se događaju u noći i stradaju „odabrani“. Niko ne zna pravi razlog takvih okrutnosti, ali su svi stanovnici Smiljevaca u strahu - to je strah od nepoznatog, stranog, drugog. Iako se strah drugačije manifestira, ipak je rat svojevrsni pokretač straha jer su i ubistva u selu posljedica rata.

Ovdje je važno upozoriti na još jednu važnu razliku između dvije skupine ljudi i njihovog suočavanja sa strahom: Zadrani pred svojim strahom postaju aktivni. Bježeći iz grada, to jest bježeći od rata kao uzroka straha, oni poduzimaju nešto da svoj strah savladaju, u čemu umnogome i uspijevaju. Dolaskom na selo potiskuju, a ponekad i potpuno zaboravljaju strah od smrti. Smiljevčani, naprotiv, ne poduzimaju ništa da se oslobode svoga straha, odnosno da se suoče s njim te su zapravo pasivni posmatrači događaja. Iako o njemu ne govore, strah pred smrću, odnosno strah da bi i sami mogli postati žrtve, jasno je izražen.

$\mathrm{Na}$ osnovu navedenoga možemo konstatirati da na razini cijelog romana dominira diskurs straha. On se javlja u različitim intenzitetima - snažnije u gradu, a na selu u nešto blažem obliku, no i tamo je itekako prisutan. Osim straha od smrti kao najsnažnije izraženog, ujedno i pokretača radnje romana, javlja se i strah od drugog/drugačijeg, strah od nepoznatog i strah od nasilja. Različito je i na koji način svaki od likova podnosi vlastito stradanje. Ovdje se pod stradanjem ne misli samo na okončanje života ili fizičku bol, nego i na paniku, razaranje doma, gubitak voljene osobe te osjećaj nemoći ili krivnje.

$\mathrm{Na}$ koncu, sve ono od čega su pobjegli, vremenom počinje da proganja likove. Odraz užasnih i mučnih događaja kojim su svjedočili i koje su zatvorili u sebe, smještajući se na sigurno, iz dubine psihe izranja na površinu. Prije svega se to događa kod Enesta Donera. Naknadno i nesvjesno javlja se „prigušeni osjećaj krivnje“ koji se odražava u snovima. Prema Freudu, „san je rezultat naše sopstvene duševne delatnosti““, 32 dok Maury naglašava da „sanjamo o onome što smo videli, rekli, željeli ili uradili““.33 U ovom slučaju Doner je, prvo, svjedočio zastrašujućem prizoru i, drugo, nije ništa uradio za ljude koji umiru. Stoga se u snovima javlja svojevrsni osjećaj krivnje. Tako je vremenom „mirni i bezbrižni Ernesto počeo gubiti živce i zapadati u čamotinju“ te je dvaput „usnio one pokopane u podrumu za bombardmana, ali nekako čudno, u isti mah kao da je i on pokopan s njima". ${ }^{44}$ Simboličnim snom Desnica zapravo osvjetljava unutrašnje stanje Ernesta Donera. On sanja da je

\footnotetext{
V. Desnica, Zimsko ljetovanje, 156.

Sigmund Frojd, Tumačenje snova, sv. 1, Beograd 1970., 52.

33 Isto, 11.
} 
zarobljen zajedno sa ostalim, što zapravo i jeste, samo se to ocrtava na nešto drugačiji način. Posrijedi je dvostruko zarobljeništvo. S jedne strane, riječ je o fizičkom „zarobljeništvu“, koje se manifestira ograničenom putanjom kretanja, životom na selu, kojem ni po čemu ne pripada, bez mogućnosti odlaska/pomjeranja. S druge strane, tu je i moralno „zarobljeništvo“, uzrokovano ravnodušnošću nad tuđom nesrećom. Stoga bismo njegov postupak mogli okarakterizirati kao svojevrsni oblik grijeha, koji se manifestira kroz slike umrlih/ umirućih kojima je svjedočio u budnom stanju, a koje u snovima počinju da ga proganjaju, stvarajući osjećaj krivnje, koji se javlja znatno kasnije, ali se ipak javlja. ${ }^{35}$

Ernesto Doner nije počinio nikakvo zlo, ali nije učinio ni nešto dobro. On je, spašavajući vlastiti život, užurbano prošao pored mrtvih, kao i ljudi zatrpanih u podrumu, kojima je pomoć bila potrebna. Upravo zbog toga što ništa nije učinio, krivnja se manifestira kroz snove, a funkcionira kao moralna opomena. Njegov osjećaj krivnje je racionalan i ima funkciju moralnog usavršavanja jer se neprestano „hvata u koštac“ sa samim sobom, iznova propituje svoje postupke, a osjećaj tuge i mrzovolje jasan je pokazatelj da Doner žali zbog onoga što je propustio uraditi.

$S$ druge strane, njegov se san u simboličkom smislu može protumačiti i kao najava koja dolazi iz dubine nesvjesnog i koja mu arhetipskim šiframa signalizira neumitni kraj, odnosno predskazuje nesreću koja će se uskoro dogoditi. Nesreću sa kojom će se i ostali likovi romana suočiti, ali najprije Ernesto - lik kroz koji se ponajbolje ocrtavaju tragika, apsurdnost rata i čovjekovo nastojanje da od smrti pobjegne. Mirnog i sunčanog poslijepodneva dogodit će se tragedija jača i veća od bilo kakve eksplozije: seoski prasac Migud otkida i proždire dio Špižmičinog lica. Slika stradanja bebe, u kojoj je do detalja opisano kako životinja grize dijelove djevojčičinog tijela, najpotresnija je slika cijelog romana i efektan prizor čovjekovog nestajanja:

Po mekom licu razlio se strah, da se čas kasnije raspline u osmijeh u kome iz krezubih ustašca sinu dva donja sjekutića i umijesi se rupica na obraščićima. (...) Ali, očice su uvijek, i kroz osmijeh, malko zaplašene, i taj osmijeh kao da hoće da učara nepoznatu zlu silu. Migud ponovo njuška; četiri mala udaha, pa izdah (...) dakle, ipak je šala, to se samo igra!... Ali onda, jednim mahom Migud poremeti redoslijed, prekide igru grdnim groktanjem - dijete se uskosi, razložno zamlatara ručicama - i razvaljene ralje životinje padoše po djetencetu. Mala se zacenu - prejak bol zakašnjavao je provalu glasa, tako da je trebalo jezivo dugo vrijeme od ugriza do vriska - lice se jarko zacrveni, vjeđe nabreknuše u debele nabore koji su postepeno modrili, a u četvrtasto razjapljenim ustašcima pokaza se resica pod jezikom.

34 V. Desnica, Zimsko ljetovanje, 147.

35 Marin Biondić objašnjava to ovako: „Osjećaj krivnje može biti racionalan s obzirom na moralno zlo koje smo počinili ili iracionalan ako nismo učinili ništa loše, a ipak osjećamo krivnju. Ovakvo određenje racionalnosti osjećaja krivnje ima svoje opravdanje u samom činu, koji može biti moralno ispravan ili pogrešan. To je prikladnost osjećaja krivnje spram samog čina. S druge strane; bez obzira na prikladnost osjećaja krivnje spram čina; možemo biti racionalni ili iracionalni u stupnju u kojemu dopuštamo da taj osjećaj vlada našim životom. Ukoliko osjećaj krivnje ima funkciju moralnog usavršavanja, možemo ga smatrati racionalnim, ali ako osjećaj krivnje djeluje destruktivno na samu osobu i uništava sve ostale aspekte života, možemo ga smatrati iracionalnim. To je racionalnost osjećaja krivnje spram življenja osobe uopće." Marin Biondić, Smrt. Priroda i vrijednost prenatalnog i postmortalnog nepostojanja, Zagreb 2015., 181. 
Drugi ujed pade na djetinje lice i zbrisa izraz bola prije nego je vrisak i prolomio. Tako se sve svrši bezglasno. ${ }^{36}$

U završnom segmentu naracije Desnica donosi snažan i neočekivan prevrat u radnji i sudbini likova te jednu sasvim drugačiju sliku smrti. Smrt bebe nije rezultat ni ratnog ni ljudskog nasilja, nego životinjske potrebe za hranom. Ova smrt, pored toga što uzrokuje stres i egzistencijalno ništavilo, simbolički ukazuje na svirepost rata i nesreće od koje su ljudi s početka romana pobjegli, uvjereni da

(...) strahote koje su doživjeli i svojim očima vidjeli predstavljaju krajnji ili jedan od krajnjih stepenova zla koje se na svijetu može dogoditi; nešto više i gore od toga njihova mašta nije mogla da zamisli. Odatle je slijedila sigurnost da sve to u najkraće vrijeme mora da prestane, već i zato što se više od toga ne bi moglo podnijeti. ${ }^{37}$

Sigurni da su dolaskom u Smiljevce izbjegli nasilnu smrt uzrokovanu ratom, likovi ovog romana na kraju se suočavaju sa „tragičnim događajem simboličke vrijednosti“ kojim se njihov boravak u Smiljevcima okončava, jer smrću bebe „kao da se najavljuje ishod rata po zadarske građane; neovisno o nacionalnoj i ideološkoj pripadnosti, oni u konačnici bivaju pojedeni od 'drugih'“. 38 Smrt bebe zapravo je pokazatelj u kojoj mjeri rat uništava svaki oblik racionalnog kontinuiteta. Događaj je najtragičniji za roditelje, Ernesta i Lizetu. Upravo su oni, pored Špizmice, najviše stradali jer, prema Freudu, smrt djeteta za roditelje predstavlja uništenje života, vlastitih nada, ponosa i sreće. Ali nakon Špižmičine smrti ništa više nije isto ni za ostale likove; izgubljena je svaka nada i vjera u svijetlu budućnost, a ostaju samo muk, nevjerica, praznina i jasan pokazatelj da nema bijega od smrti i da su oni dolaskom u Smiljevce ne pobjegli, nego za neko vrijeme pomjerili/odgodili vlastitu smrt.

U konačnici romana događa se upravo ono što Maurice Blanchot naglašava kada govori o smrti i čovjekovoj želji da se od nje pobjegne. Zadrani se, na jedno vrijeme, uspijevaju skriti pred smrću, ali „to skrivanje moguće je upravo zato što je sama smrt neprekidno bekstvo ispred smrti, jer je ona dubina prikrivanja. Tako skriti se od nje znači na izvestan način skriti se u njoj. “39 Iako smrt bebe nije njihova vlastita smrt, ona je ta koja ih „uzima“ na kraju - i takvi neodoljivo podsjećaju na posljednju sliku koju su sa sobom ponijeli iz Zadra, sliku mačke zarobljene u pustoj magazi sa zatvorenim prozorima, koja se „verala nemoćno po glačini stakla izgladnjela i užasno omršala“. ${ }^{40}$ Upravo ova slika efektan je prikaz ljudi, izbezumljenih od užasa koji se oko njih događa, a podrum nije nišsta drugo do metafora njihovog života.

Tokom cijelog romana neprestano se nameće pitanje koje u završnici svoga rada $O$ smrti opservira Tugendhat: Zašto se plašimo da uskoro umremo? Prema Tugendhatu, jedini mogući egzistencijalističko-filozofski odgovor glasi: zato što „smrću gubimo priliku da životu

\footnotetext{
6 V. Desnica, Zimsko ljetovanje, 169-170.

Isto, 61.

38 V. Rismondo, „Roman Zimsko ljetovanje Vladana Desnice u svjetlu kulturalnih studija“, 132.

39 Moris Blanšo, Eseji, Beograd 1960., 22.

40 V. Desnica, Zimsko ljetovanje, 66.
} 
damo smisao ili da mu damo više smisla“. ${ }^{41}$ U Zimskom ljetovanju situacija je pomalo drugačija od očekivane, likovi ostaju na životu, ali smrt drugih, posebno smrt bebe, za svakog od likova predstavlja gubljenje smisla i nade u izbavljenje, a život postaje besmisao društvene i pojedinačne egzistencije. Likovi tako, uslovno kazano, umiru jer gube svaku priliku da životu daju neki viši smisao, kako navodi Tugendhat. Smrt je u ovom romanu prisutna od samog početka, i u svijesti i podsvijesti likova, te se reflektira na različite načine: od iskasapljenih tijela na ulici, starosti (popadija Darinka), bolesti (Lina, šjor Karlo, Nikica), preko straha od smrti i misli o nestajanju, koje postaju sastavni dio života.

$\mathrm{Na}$ početku romana bijeg iz razorenoga grada pruža grupi Zadrana nadu da je moguće savladati rat, pobjeći od nesreće i smrti, a na kraju romana ta se nada smrću bebe u potpunosti slama. Bijeg od rata i njihovo uvjerenje da su u tome uspjeli nije ništa drugo do konstantna opomena koliko su, zapravo, blizu smrti. Tematsko-motivsku okosnicu romana čini strah od smrti, koja je ovdje data kao sastavni dio života, ona je u svijesti i podsvijesti, pokreće i određuje stvari i događaje. Iz razorenoga grada smrt se preseljava u čovjeka, prisutna je u svim segmentima njegovog života, postaje dio njegove svakodnevnice, ono bitno egzistencijalno i društveno. Uništenje i prolaznost eksplicitno ili implicitno prisutni su na razini cijelog romana. Osim što prikazuje jedan od najvećih strahova - strah od smrti - te čovjekovo suočavanje sa promjenama u sebi odnosno oko sebe, Desnica ovim romanom „prelazi granice tematiziranog vremena i prostora otvarajući mogućnost čitateljske identifikacije/prepoznavanja u drugim vremenima i na drugim prostorima“. ${ }^{42}$ Prikazom pojedinačnih ljudskih sudbina i konkretnim udesom pojedinaca, kao i prikazom bombardiranja i razaranja grada, Desnica nastoji dati što obuhvatniju i efektniju sliku snažnih historijskih promjena, koje se najčešće i najrazornije odražavaju na živote malih, običnih ljudi, pretvarajući njihove sudbine nerijetko u tragične.

\section{$\cos$}

\section{Literatura}

Marin Biondić, Smrt. Priroda i vrijednost prenatalnog i postmortalnog nepostojanja, Zagreb 2015.

Moris Blanšo, Eseji, Beograd 1960.

Tihomir Brajović, „Ironija i kolektivna memorija: Desnica, Krleža, Andrić“, Desničini susreti 2010. Zbornik radova (ur. Drago Roksandić i Ivana Cvijović Javorina), Zagreb 2011., 31-38.

Miljenko Buljac, „Poetika Zimskog ljetovanja - prvi tipološki krug literarnosti Vladana Desnice“, Vladan Desnica i Split 1920. - 1945. Zbornik radova sa znanstvenog skupa Desničini susreti 2014. (ur. Drago Roksandić i Ivana Cvijović Javorina), Zagreb 2015., 343-358.

Vladan Desnica, Zimsko ljetovanje, Zagreb 1968.

Davor Dukić, „Nekoliko imagoloških opaski o Zimskom ljetovanju i Desničinim susretima“, Desničini susreti 2005. - 2008. Zbornik radova (ur. Drago Roksandić i Ivana Cvijović Javorina), Zagreb 2010., 149-156.

$41 \quad$ E. Tugendhat, $O$ smrti, 36.

42 D. Dukıć, „Nekoliko imagoloških opaski o Zimskom ljetovanju i Desničinim susretima“, 153. 
EpIKur, „Pismo Menoikeju“, u: Branko Bošnjak, Filozofija od Aristotela do renesanse i odabrani tekstovi filozofa, Zagreb 1983., 144-153.

Sigmund Frojd, Mi i smrt. Našstav prema smrti: dosad neobjavljeni rukopisi i predavanja (prir. Žarko Martinović i Milica Martinović), Beograd 2001.

Sigmund Frojd, Tumačenje snova, sv. 1, Beograd 1970.

Bela Hamvaš, Teorija romana, Beograd 1996.

Radomir Konstantinović, „Vladan Desnica ili konačna forma“, u: Vladan Desnica, Zimsko ljetovanje, Sarajevo 1966., 181-186.

Zoran Kravar, „Zimsko ljetovanje Vladana Desnice pod ideološkokritičkim lećama“, Desničini susreti 2010. Zbornik radova (ur. Drago Roksandić i Ivana Cvijović Javorina), Zagreb 2011., 9-17.

Mišel de Montenj, Ogledi, Beograd 1967.

Marina Protrka Štimec, „Kineskim zidom odvojeni'. Politike identiteta, nejednakosti i isključivanja u Desničinu Zimskom ljetovanju“, Hrvatsko-srpski / srpsko-hrvatski interkulturalizam danas. Zbornik radova s medunarodnoga znanstvenog skupa Desničini susreti 2016. (ur. Drago Roksandić), Zagreb 2017., 199-212.

Vladimir Rismondo, „Roman Zimsko ljetovanje Vladana Desnice u svjetlu kulturalnih studija“, Split i Vladan Desnica 1918. - 1945.: umjetničko stvaralaštvo izmecu kulture i politike. Zbornik radova sa znanstvenog skupa Desničini susreti 2015. (ur. Drago Roksandić i Ivana Cvijović Javorina), Zagreb 2016., 131-143.

Mirna Sindičić SABljo, „Predodžbe o ruralnoj sredini u Zimskom ljetovanju Vladana Desnice“, Fluminensia, 23/2011., br. 1, 131-142.

Ernst Tugendhat, O smrti, Loznica 2010.

Luca VAGLIO, „Vidovi policentrizma i problematičnosti u romanu Zimsko ljetovanje Vladana Desnice“, Desničini susreti 2010. Zbornik radova (ur. Drago Roksandić i Ivana Cvijović Javorina), Zagreb 2011., 101-108.

\section{$\cos$}

\section{FEAR of DEATh in Vladan Desnica's NOVEL ZIMSKO LJETOVANJE}

The author explores an often neglected aspect of the novel Zimsko ljetovanje (Summer vacations in winter) - fear of death. The novel follows a group of people who escape the bombing of Zadar and take refuge in the nearby village of Smiljevci. Desnica uses the narrative framework of World War II to show the fates of common, marginalized people, yet the war itself is not a major theme in the book. Instead, it brings about the encounter between two groups of people and their respective cultures. Although unable or outright unwilling to accept each other, these two groups are forced to coexist in the same community. The central theme of the novel is the fear of death, while the war serves as a mere historical backdrop. The novel focuses on the suffering of individuals whose lives are overshadowed by death due to tragic historic circumst ances. Through these individual tragedies, Desnica describes the destructive power of war and evil inherent to all of history. In the novel, death is viewed as a part of life, the driving force behind circumstances and events. In the novel, characters encounter forms of death which, although not caused by bombs, are nevertheless part of the effect that war and its horrors have on the world and the human psyche. An example of this are the murders which take place in the dead of night, leaving the community reluctant to 
find the perpetrators. The most representative example of the way war reaps death even without guns is the tragic death of baby Špižmica which, laden with symbolism, takes place at the end of the novel and is brought about by Migud, the village pig. The fear of death is then replaced by despair and a confrontation with the evil within, as well as without. Thus, in Zimsko ljetovanje, death is portrayed as a part of life, always on the characters' minds either consciously or unconsciously, moving and shaping events and circumstances.

Key words: Vladan Desnica, Zimsko ljetovanje, fear, death, war, mental breakdown, the others 